\title{
A University Literacy Festival: The Impact of Connecting Children's Authors with Students, Teachers, and Librarians from Title I Schools
}

\author{
By Cynthia Dawn Martelli
}

\begin{abstract}
A literacy festival is one of the most effective ways to promote reading and fosters the idea that books make a difference, especially to under-supported students. This paper is based on a research study that focused on how a university literacy festival supported engagement and increased reading attitudes and habits for students of Title I schools. It also explores a longitudinal study that analyzed a university's literacy festival and its impact on students, librarians, teachers, children's authors, teacher candidates, and librarians from Title I schools in southwest Florida. The findings of this study suggest that a university literacy festival helps connect children with books, which can help promote a lifelong love of reading and writing. A university literacy festival featuring a variety of diverse authors presenting interactive workshops showcasing their literary craft enabled students from Title I schools to engage with the authors and to see themselves as writers and encouraged them to explore a university in their own backyard. This university literacy festival made a positive impact in the area of engagement in reading and found an increase in reading from students from Title I schools that attended the event.
\end{abstract}

Keywords: literacy festival, children's authors, Title I students, teacher candidates, reading

\section{The Impact of a University Literacy Festival on Title I School Partners}

Research shows that the highest achieving students are those who devote leisure time to reading, even when the school day and year are only mid-length and homework is not excessive. Recently, the largest-ever international study of reading found that the single most important predictor of academic success is the amount of time children spend reading books, more important even than economic or social status. And one of the few predictors of high achievement in math and science is the amount of time children devote to pleasure reading (Atwell, 2007).

Experts endorse that when children become good readers early in their schooling, they are more likely to become better readers and learners throughout their school years and beyond (Graves, 1994). Under-achieving students from a low socioeconomic status often fall behind their peers and continue to struggle to catch up with their peers academically. This achievement gap extends throughout their schooling. Thus, students low in literacy achievement often experience increased social and behavior problems and are likely to be retained; and students who are at risk for reading failure are often remediated in the lower grades in order to strengthen their literacy skills by third grade (Martella, Martella, \& Przychozin,

*Associate Professor, Florida Gulf Coast University, USA. 
2009). Students lack an essential tool for learning if they cannot read which will eventually lead to a shortage of job opportunities (Martella, Martella, \& Przychozin, 2009). Researchers agree that there is a positive relationship between students with low socioeconomic backgrounds and low academic achievement (Oxley, 2008; Tonn, 2007). The ambition of Title I was to boost local states and school districts by designating resources to targeted groups in order to escalate the level and quality of services administered to these specific students (Odden, Goetz, $\&$ Picus, 2008). It takes a village to raise a literate child. Families can make a difference. Teachers can make a difference. Community programs can make a difference. Parents, teachers, caregivers, and members of the community are all part of the village that can help support children in learning to read.

\section{A University Literacy Festival}

A literacy festival is one of the most effective ways to celebrate literacy; and it cultivates the idea that reading books makes a difference, especially to students in Title I schools. A literacy festival featuring a variety of diverse authors presenting hands-on workshops showcasing their literary craft enables students from Title I schools to engage with the authors and to see themselves as writers and illustrators. Teacher candidates engaged in delivering literacy lessons can motivate students from diverse backgrounds to develop an excitement for reading and enhance their self-efficacy and desire to become life-long readers, ideally benefitting both the community and the teacher candidate.

This paper will explore at how a university's literacy festival impacted participating students from surrounding Title I schools and how it impacted teacher candidates. It will describe the implementation of an effective community partnership that provided teacher candidates with the opportunity to apply best practices in literacy instruction with students from diverse needs and backgrounds.

\section{Community Outreach}

The vision of a university literacy festival was devised from a desire to excite and incite a love for reading in students from Title 1 schools and to provide teacher candidates with the opportunity to implement best practices in literacy instruction with students from diverse needs and backgrounds. Five districts surrounding a state university had schools designated as Title 1 schools. A committee consisting of five teacher educators, one staff member, and several teacher candidate representatives from the university's College of Education (COE) rallied together to establish an annual COE Literacy Festival. Responsibilities of the committee involved communicating with the five local districts, attending continuous meetings throughout the school year, establishing a date for the literacy festival, attaining funding, researching local and national children's literature authors to invite, organizing the schedule and activities, traveling to numerous Title I schools to deliver books to children attending the literacy festival, and visiting with the 
participating students and teachers to familiarize them with each participating author. Each year, the COE Literacy Festival Committee provides a free book from one of the featured children's authors to students from the surrounding Title I schools attending the festival. By the fourth year, the festival featured 17 children's and young adult authors and provided a free book to approximately 2,275 students attending Title I schools.

\section{Diversity in Children's Books}

The immediate task of the committee was to research a variety of children's literature authors who focused their work on diversity in order provide a venue that presented authors relevant to the invited community. Children's books are like mirrors where children can reflect on their own lives and they are also windows where children can learn about the lives of others (Persaud, 2013). Children's literature is now approximately twice as diverse as it was in 2012 according to the University of Wisconsin-Madison's Cooperative Children's Book Center (CCBC) (Colyard, 2016). By centralizing on diverse children's literature, authors would allow students from Title I schools in the local five districts to see themselves reflected in stories and also learn about other cultures. Books containing diverse casts of characters that emphasized empathy, fairness, and empowerment through words and pictures were reviewed.

\section{Field Experience}

Field experiences through service learning are a means through which teacher candidates can apply their literacy intervention knowledge, teaching skill, and principles of differentiated instruction with diverse learners. Throughout this process, teacher candidates are encouraged to think critically about how they can have a positive impact on students of diversity in their community. In addition, they are encouraged to reflect on the impact of that experience, not only in terms of the P12 students who are the recipients of that service, but also how the experience transformed them as a learner. Previous studies on service learning have used teacher candidates' self- reflections to show positive correlations between the use of service-learning and candidates' acquisition of academic knowledge and learning (Cohen \& Kinsey, 1994; Eyler, Giles, \& Gray, 1999; Gray, Ondaatje, Fricker, \& Geschwind, 2000; McKenna \& Rizzo, 1999). Research also clearly demonstrated that service-learning had a strong effect on teacher candidates' self-esteem, confidence in social skills, increased sense of social responsibility, and sense of connectedness to their community (Eyler, Giles, \& Gray, 1999). Eyler, Giles, and Gray (1999) found that the quality of the servicelearning placement, structured reflection opportunities, and the intensity and duration of the community service component could affect student outcomes. An effective service learning opportunity must not only meet the needs of the teacher candidates, but it must also meet the needs of the community. 


\section{The College of Education Literacy Festival}

The annual COE Literacy Festival is located on the center library lawn of the university. Each student from a Title I school in the five area counties that participated in the COE Literacy Festival received a free book from a featured children's author prior to their arrival on campus. This allows time for COE teacher candidates to visit schools to integrate the books across the disciplines, time for students to read the books, and time to study the authors and their literary crafts. The festival was located on the library lawn in the center of the university campus. Tables surrounded the area for author book signings where each student had the opportunity to have their book signed by the corresponding author. Nearby buildings were utilized for author interactive sessions. A pavilion offered an outdoor space for a storyteller performer. In order to fulfill their field experience requirements, the College of Education teacher candidates had designated areas around the library lawn to deliver their read-alouds and literacy activities as well as STREAM activities with small groups of students from Title I schools throughout the day. A digital literacy session was also available for students to attend.

\section{Service to the Community}

The university's COE Literacy Festival focused on diversity in children's literature. The central target population was a diverse group of students from Title 1 schools in five local districts, in conjunction with opening the literacy festival to the community. Several teacher educators from the COE Literacy Festival Committee delivered books to each designated Title I school two months before the event. Teacher educators and the College of Education teacher candidates had the unique opportunity to reach out to students by visiting selected classrooms to inform students of the visiting children's literature authors. These classrooms perused the authors' websites, book trailers, author interviews, and other published books from the invited authors. Several teachers conducted read-alouds from the authors' literature books that were delivered to their students. Other teachers utilized paired readings of the authors' books, and other teachers committed time to their students to read the books independently while following up with small group and whole class discussions.

During the festival, students and teachers from the selected Title I schools participated in authors' workshops and book signings. The workshops were engaging and interactive with the authors sharing their literary craft and their own life experiences that became inspirations for their stories. Teacher candidates were given time before and after the students arrived to visit with the authors, ask questions, and gain insight into the art of writing and illustrating children's books. 


\section{Service to the Teacher Candidate}

The COE Literacy Festival provided an exclusive opportunity for over 120 College of Education literacy students to participate in a service-learning field experience. Service-learning field experience revolves around experiential education where learning occurs through action and reflection as students seek to accomplish authentic objectives for the community and involves a deeper understanding of essential life skills (Wolpert-Gawron, 2016). This experience required candidates to interact with students from Title I schools by engaging them in read-alouds with hands-on, meaningful literacy activities. The purpose of the read-aloud with inclusive literacy activities was to prompt teacher candidates to select high quality children's books, create an opportunity for teacher candidates to make connections between literature and engaging students with a text, and give teacher candidates ownership and control over literacy activities. They were required to develop appropriate strategies to extend the book chosen for their read-aloud and to encourage students to think critically. The goal of the festival was to connect the teacher candidates and the community and to make the literacy world accessible to everyone by celebrating the importance of reading.

In order to accomplish this goal, candidates were required to provide quality activities that would promote and encourage lifelong reading and build continuing partnerships with local districts and community. The objective for each teacher candidate was to choose diverse books to read aloud and to encourage and motivate children to love literature. The teacher candidates worked in groups of three to create and deliver a read-aloud lesson. Every group researched and chose a children's book to read aloud, developed a detailed plan on how they would introduce and read the book, such as what questions they would ask before, during, and after reading, and constructed comprehensive literacies activities that would extend the book and motivate students. Their study of children's literature involved critical literacy and analysis of texts that encompassed cultured uses of language and literary techniques used by authors to capture the human experience. Analyzing text from differing viewpoints, the teacher candidates utilized inclusive literacy strategies including prediction, clarifying, drawing inferences, and visualizing. Teacher candidates were required to have students question and examine story structure leading to discussions revolving around author's purpose, identifying the central issue, and analyzing characters' emotional responses and viewpoints in an effort for students to inquire into questions involving purpose and meaning in their own lives. After delivering the lesson at this literacy festival, the teacher candidates wrote a reflection on their experience, concentrating specifically on their impact on students from Title I schools.

On the day of the COE Literacy Festival, a group of teacher candidates from the Honors Program shadowed the participating children's literature authors during their interactive workshops and book signings. This opportunity gave these future teachers insight into the tools and techniques of the authors' language and storytelling used to craft their books.

The College of Education teacher candidates are central to the university's partnerships within the community. This service-learning field experience presented 
opportunities for teacher candidates to combine classroom pedagogy with community action. Teacher candidates were able to embed abstract classroom concepts into concrete form in order to increase students' critical thinking and engagement in reading. There was not only a service provided to the community, but academic learning was strengthened in the teacher candidates' learning; and civic and social responsibility for the community was advanced.

\section{Methods and/or Techniques}

A longitudinal research study was conducted regarding perceptions of a university literacy festival from participating children's authors, librarians, teachers, teacher candidates, and selected focus students throughout the semester. This inquiry was framed as a longitudinal qualitative case study covering four annual literacy festivals, examining the efficacy of a university's literacy festival in supporting engagement in reading and increased reading attitudes and habits for students in Title I schools. The research questions were:

In what ways does a university's literacy festival support engagement in reading and increase reading attitudes and habits for students in Title I schools?

What are the perceived benefits of a university's literacy festival for COE teacher candidates, librarians, teachers, and students from Title I schools?

In what ways are the authors affected by a university's literacy festival?

\section{Data Sources}

Data included electronic and hard copy survey responses from open-ended questions $(\mathrm{n}=5)$ and included six informal interviews, eight video interviews, and 14 quick-writes conducted with authors, librarians, teachers, teacher candidates and selected focus groups of students throughout four years. The data were analyzed for themes and clusters of meaning to capture the essence of the participants' experiences. Data analysis of participants' statements, as well as emerging themes were analyzed by highlighting significant statements from participants, and valuing each response; these statements were then organized into clusters of meaning or themes (Creswell, 2013). Data were coded using and inductive process beginning with open codes which were then put into themes and categories that became broader through analysis (Creswell, 2013). Data were reduced through iterative rounds of examination in which codes were grouped into categories and then into themes.

\section{Librarians}

Librarians in the schools that participated in the COE Literacy Festival noted that circulation numbers were quite low and that the libraries were rarely used to find books to read for pleasure prior to the delivery of books from author's 
participating in the literacy festival. In addition to teacher educators and the College of Education teacher candidates visiting classrooms to deliver books and promote the authors participating in the literacy festival, the librarians from Title I schools met with classrooms scheduled to attend the COE Literacy Festival to further study the authors and their writing process. They read aloud passages from the authors' books to engage students, displayed books that were available from the authors in the schools' libraries, and made them available for students to check out. Three librarians showcased the visiting authors through displays featuring photographs and interesting facts on bookshelves located in the libraries. Most librarians made sure the books published from the authors participating in the festival were located in plain view for students to find easily when entering the library. One librarian even held a book club after school for students interested in discussing the books they were reading for the COE Literacy Festival. She expressed her joy over the students attending the book club and shared that excitement about the books was contagious. Overall, the librarians expressed that there was an increase in books checked out from both the participating authors' books as well as other books during the months that led up to the literacy festival. They also shared that there was even a "buzz" or excitement in the schools about meeting the authors of the books they were reading.

\section{Teachers}

The majority of teachers from the Title I schools who attended the literacy festival stated that they spent time with their students reading the authors' books and designing higher-level, critical thinking strategies. They also reported that they spent time studying how authors use tools and techniques of language and storytelling to craft a piece of writing with narrative elements and literary devices. One teacher emphasized that her students' discussions not only focused around tolerance but also broadened to respecting and understanding all of the different cultures in their community. Another teacher confessed that after witnessing her own students remarkably engaged in the diverse children's books given to her class for the COE Literacy Festival, she took a second look at her own classroom library and realized that she needed to include many more books that reflected and honored the lives of her students.

Several teachers surveyed mentioned how the read-alouds built on important foundational skills by introducing vocabulary, providing a model of fluency and expressive reading, and helped students recognize what reading for pleasure was all about. These teachers expressed the desire to include more read-alouds in their own classrooms to not only support the development of reading and writing skills but to also build on their knowledge about the world and their place in it. Teachers also mentioned their gratitude toward the authors offering continuous interactions with their students through social media in the form of blogs, Skype, Facebook, Twitter, writing clubs, and other online sources. Through the process of engaging with the children's literature authors, all teachers agreed that their students came to see themselves as writers and expressed a desire to share their thoughts with others 
with great enthusiasm. This enthusiasm has been shown to foster a lifetime of reading (Clark \& Douglas, 2011).

\section{Authors}

Children's and middle school authors were selected based on their books where strong, diverse characters would give the opportunity for students from Title I schools to see themselves and their culture. Each author was video-interviewed to share the impact their books have on students of Title I schools and the benefits of participating in the COE Literacy Festival. Three authors describe their experience.

Sharon Flake, author of Unstoppable Octobia May and The Skin I'm In, described that most of her books revolve around life in the inner city since she, herself, grew up in the inner city (Flake, 2015; 2018). It is her home and what she knows. Sharon feels as though people who live in the inner city are not fully understood or appreciated. She wants her readers to know that you don't always know someone until you are willing to get in the skin they are in. However, she stresses that every story is worth telling and hearing, and that every person has a voice.

Kentrell Martin, author of Shelly Adventures books, wishes to help embrace the gap between the deaf and the hearing world. He feels the best people to reach are children so as they grow older they are the generation that can help start be a part of that change. David and Marni Martinez write a series books titled Signamalz that teaches sign language to children. Their focus is to help children increase their communication with deaf hearing students. The three authors agree that if students are able to communicate better with each other that they would discover more commonalities than differences.

Sherri Winston is the author of President of the Whole Sixth Grade, The Kayla Chronicles, and The Sweetest Sound (Winston, 2016; 2009; 2018). She describes the benefits of participating in the COE Literacy Festival. Sherri expresses that not only do students from Title I schools get to visit and talk to authors, they also have the opportunity to place their feet on a college campus. She knows from growing up in a neighborhood where $95 \%$ of children thought that going to college was like going to mars; it just wasn't done. Exploring a college campus throughout the COE Literacy Festival makes the students see that college is real and it is attainable.

\section{College of Education Teacher Candidates}

The purpose of this community partnership for the teacher candidates was to select high-quality children's books, create an opportunity for them to make connections between literature and student engagement with a text, and provide them with ownership and control over literacy activities and encourage them to develop appropriate strategies to extend the book for elementary students to think critically. This unique service-learning field experience granted the university's 
College of Education teacher candidates the opportunity to administer best teaching practices in literacy instruction with students from diverse needs and backgrounds while serving the needs of their community. Through read-alouds with inclusive literacy activities and hearing about the authors' real-life experiences in their stories and writings, students from Title I schools gained a deeper appreciation of who they are and who the people are around them.

Analysis of reflections from teacher candidates revealed that most of the candidates self-identified as being more knowledgeable about students from Title I schools, felt more self-confident in the areas of positively contributing to the needs of the community, and expressed more excitement about teaching because of their experiences interacting with these students from diverse backgrounds. One teacher candidate shared the following:

I enjoyed this experience because I had the opportunity to talk to one of the authors about her writing and what inspires her to write. It was great to hear how she is inspired by her dog and draws on her life experiences for her books. I think the most memorable part of this experience was the lengthy discussion I had with one of the fifth-grade teachers. She was talking to me about the daily challenges that her students carry with them, from difficult lives at home. They have a washer and dryer at the school so that the children can have clean clothing. She was going to be visiting a student in the hospital later that day. This boy's parents had neglected to take their son for medical services for sickle-cell anemia, arranged at no cost, even after their daughter had died from the blood disorder...She described the dual role she plays most days - not just as a teacher, but a parent as well. She was incredible, and I made sure to tell her! The most important lesson I learned from this experience is that being welcoming, comforting, and accepting makes such a difference. It is what gives us the opportunity to connect with students. They are willing to listen and engage when you make the effort to ask and not to just tell. It was a pleasure to work with my group members, and we worked well as a team. Sharing the experience with my peers allowed us to provide each other with support and feedback!

The teacher candidates collaborated, incorporating successful strategies for teaching reading, and discovered the importance of reading for enjoyment and learning while delivering read-alouds and interacting with students from Title I schools. The read-alouds with inclusive literacy activities centered around encouraging students to reflect on their own individual cultures and histories, their backgrounds, and their values in hopes that they would begin to broaden their perspective and recognize diversity in backgrounds and beliefs. In another example, a teacher candidate voiced her opinion:

At the literacy festival, I felt this energy that is so characteristic of kids. The enthusiasm they had because they were discovering new things at every corner changed the air of the place very quickly. One of the teachers even said to me that her students had become really excited from the moment they had seen the entrance of the university... Even when this was my first time reading aloud, I understood the importance of having experience in the field from the beginning. I was not perfect by any means, and as I look back, I find many things that I need to improve, but this is a necessary step that I need to take so that I can become more competent as a teacher. 
The teacher candidates recognized that choosing authentic children's books was a powerful means to help children understand their homes, communities, and the world. They stated that knowing their community was of the utmost importance to constructing inclusive, multicultural activities that reflected the backgrounds and experiences of the students participating in the COE Literacy Festival. The targeted goal was to allow teacher candidates to critically think about and analyze information while becoming actively involved in the learning process. Some teacher candidates needed to modify some teaching techniques in order to increase the success and effectiveness of their activities to meet the needs of their students. In general, teacher candidates stated that they constructed open-ended questions to foster a feeling of emotional safety by respecting every student's opinion and encouraging all students to be respectful of one another.

\section{Students from Title I Schools}

At the COE Literacy Festival, students of Title I schools had the opportunity to listen to children's literature authors read aloud their books, as well as observe the College of Education teacher candidates implement read-alouds with literacy activities at a university campus. Students enthusiastically expressed their own life experiences and soon came to see themselves as writers and readers through the interactions with the children's literature authors and the College of Education teacher candidates. One student expressed:

My mom goes to this university, but I did not know this is what it looked like! I am so proud of her! I need to find my author to sign my book. This is the first book I ever read on my own! It is like he grew up in my town! I have so many questions to ask $\operatorname{him}$ !

The students were excited by the opportunity to meet authors through book signings and workshops and shared that the experience made the authors themselves accessible and real to them. They expressed that during the author's workshops and book signings, the authors became relevant and were less intimidated by the reading and writing process. They felt that they were able to discover the ideas behind books and could identify with the authors' stories of struggles. They were enlightened to the joys of writing and publishing. The students discovered that authors were ordinary people, that writing was rarely easy, and that the only thing stopping them from writing was perseverance. A student in middle school voiced:

Our author worked with us on our own stories today! She told me that I have a good story for others to hear and learn from. I am excited to share about the story of my brother and am amazed that I can help people just by them reading my story. 


\section{Challenges}

Even though the literacy festival was a one-day event, the preparation was continuous throughout the year and involved invitations of authors and schools, scheduling, buying and delivering books to students, school visits to the local districts from our $\mathrm{COE}$ students and faculty in order to promote literacy through the authors' books and websites, and preparation of COE students in creating and delivering read-aloud lessons with activities and ongoing research. Two internal grants and an outside sponsor were obtained from the university in order to provide books and cover the cost of authors' honorariums.

The reflections provided insight into the effectiveness of literacy festival to both the teacher candidates and the community, and also offered insight into how the service-learning field experience could be improved. As a result, schedules for teacher candidates' arrival times will be adjusted to anticipate late bus arrivals and campus logistics.

\section{Conclusions}

Literacy is the foundation of an effective society and a university's literacy festival can support engagement and increase reading attitudes and habits for students of Title I schools. A literacy festival is one of the most effective ways to promote reading and fosters the idea that books make a difference, especially to under-supported students. Students from Title 1 schools are typically students that are low-achieving, come from the communities highest-poverty schools, are of limited English proficiency, are migratory, and most often are young children in need of reading assistance (U.S. Department of Education, 2004).

The goal of the COE Literacy Festival was to invite diverse children's literature authors that would create self-worth within students and allow them to connect with themselves and their culture through literature on a deeper level. The librarians of the participating schools took advantage of the opportunity to entice students to the library through the author displays, easy access to authors' books, read-alouds, and an after-school book club. Such hype helped create a buzz among the students, creating more traffic in the libraries; consequently, increasing the circulation of books.

The findings of this study suggest that a university literacy festival helps connect children with books, which can help promote a lifelong love of reading and writing. In addition to the children's literature authors' workshops and book signings at the COE Literacy Festival, students had the opportunity to visit numerous read-aloud and literacy activities implemented by the teacher candidates. This gave the teachers of Title I schools the opportunity to observe the importance of read-alouds with inclusive literacy strategies and motivated them to implement them in their own classrooms.

This university literacy festival made a positive impact in the area of book promotion and engagement in reading and found an increase in reading from students from Title I schools that attended the event. Working with the community 
to create a literacy festival can help connect children with books which can help promote a lifelong love of reading and writing. Perceptions from teacher candidates indicated that the COE Literacy Festival made them feel as though they made a worthwhile contribution to the community. Teacher candidates learned to work with classmates, share ideas, and teach together as they planned lessons as part of a team. They indicated through their reflections that they enjoyed working with diverse students and that the experience was helpful as they prepared for their teaching career. The teacher educators and teacher candidates quickly discovered that the more they familiarized themselves with the community and the students that were attending, the deeper, more meaningful, and relevant their experience were.

As a university seeks to prepare educators to positively impact their community, teacher candidates must participate in that community. Participation in effective service-learning field experiences can ensure that candidates learn the needs, challenges, and opportunities of working in settings with students from diverse backgrounds. To prepare future teachers to mature into educators who can effectively engage and positively affect the world, they need to be given the opportunity to take risks, to understand the needs of the community, and how to effectively meet those needs in order to improve the quality of life in the community. A literacy festival can address and meet those needs. It takes a village of parents, teachers, caregivers, and members of the community to help support children in learning to read. It takes a village to ignite that passion of reading for a lifetime.

\section{References}

Atwell, N. (2007). The Reading Zone: How to Help Kids Skilled, Passionate, Habitual, Critical Readers. Scholastic Teaching Resources.

Clark, C., and Douglas, J. (2011). Young People's Reading and Writing: An in-Depth Study Focusing on Enjoyment, Behaviour, Attitudes and Attainment. London: National Literacy Trust.

Cohen, J., \& Kinsey, D (1994). "Doing Good" and Scholarship: A Service-Learning Study. Journalism Educator, 48(4), 4-14.

Colyard, K. (2016, September 14). How Diverse is Children's Literature? Bustle.

Creswell, J. W. (2013). Qualitative Inquiry and Research Design: Choosing among Five Approaches. SAGE Publications.

Eyler, J., Giles, D. E., \& Gray, C. J. (1999). Where's the Learning in Service-Learning? Jossey-Bass Publishers.

Flake, S. G. (2018). The Skin I'm in. Jump at the Sun.

Flake, S. (2015). Unstoppable Octobia May. Scholastic Press.

Graves, D.H. (1994). A Fresh Look at Writing. Heinemann.

Gray, M, Ondaatje, E., Fricker, R., \& Geschwind, S. (2000). Assessing Service-Learning: The Benefits of Service Learning for Students. Change, 32(2), 30-41.

Martella, N., Martella, R., \& Przychozin, A. (2009). Analysis of Corrective Reading Research. Journal of Direct Instruction, 5(1), 37-65. 
McKenna, M. W., \& Rizzo, E. (1999). Outside the Classroom: Student Perceptions of the Benefits of Service Learning. Journal of Prevention and Intervention in the Community, 18, 111-123.

Odden, A. R., Goetz, M. E., \& Picus, L. O. (2008). Using Available Evidence to Estimate the Cost of Educational Adequacy. Education Finance and Policy, 3(3), 374-397.

Oxley, D. (2008). From High School to Learning Communities: Five Domains of Practice. Northwest Regional Educational Laboratory.

Persaud, A. D. (2013, February 4). What does this Book Have to Do with me? Why Mirror and Window Books are Important for All Readers. The Open Book Blog.

Tonn, J. L. (2007). States Seeking Greater Flexibility under the NCLB. Education Week, 26, 1-3.

U.S. Department of Education. (2004, September 15). Title I - Improving the Academic Achievement of the Disadvantaged. U.S. Department of Education.

Winston, S. (2009). The Kayla Chronicles: A Novel. Little, Brown and Company.

Winston, S. (2016). President of the Whole Sixth Grade. Little, Brown and Company.

Winston, S. (2018). The Sweetest Sound. Little, Brown and Company.

Wolpert-Gawron, H. (2016, November 7). What the Heck is Service Learning? Edutopia. 
